\title{
Isolation of Petrocidin A, a New Cytotoxic Cyclic Dipeptide from the Marine Sponge-Derived Bacterium Streptomyces sp. SBT348
}

\author{
Cheng Cheng ${ }^{1}$, Eman M. Othman ${ }^{2,3}$, Helga Stopper ${ }^{2}$, RuAngelie Edrada-Ebel ${ }^{4}$, \\ Ute Hentschel 1,5 (iD) and Usama Ramadan Abdelmohsen 1,6,* \\ 1 Department of Botany II, Julius-von-Sachs Institute for Biological Sciences, University of Würzburg, \\ Julius-von-Sachs-Platz 3, D-97082 Würzburg, Germany; tj.cheng@hotmail.com \\ 2 Department of Toxicology, University of Würzburg, Versbacher Str. 9, D-97078 Würzburg, Germany; \\ eman@toxi.uni-wuerzburg.de (E.M.O.); stopper@toxi.uni-wuerzburg.de (H.S.) \\ 3 Department of Analytical Chemistry, Faculty of Pharmacy, Minia University, Minia 61519, Egypt \\ 4 Strathclyde Institute of Pharmacy and Biomedical Sciences, University of Strathclyde, The John Arbuthnott \\ Building, 27 Taylor Street, Glasgow G4 0NR, UK; ruangelie.edrada-ebel@strath.ac.uk \\ 5 GEOMAR Helmholtz Centre for Ocean Research, RD3 Marine Microbiology, and Christian-Albrechts \\ University of Kiel, Düsternbrooker Weg 20, D-24105 Kiel, Germany; uhentschel@geomar.de \\ 6 Department of Pharmacognosy, Faculty of Pharmacy, Minia University, Minia 61519, Egypt \\ * Correspondence: usama.ramadan@mu.edu.eg; Tel.: +20-86-2347759; Fax: +20-86-2369075
}

Received: 25 October 2017; Accepted: 16 November 2017; Published: 6 December 2017

\begin{abstract}
A new cyclic dipeptide, petrocidin A (1), along with three known compounds-2,3dihydroxybenzoic acid (2), 2,3-dihydroxybenzamide (3), and maltol (4)-were isolated from the solid culture of Streptomyces sp. SBT348. The strain Streptomyces sp. SBT348 had been prioritized in a strain collection of 64 sponge-associated actinomycetes based on its distinct metabolomic profile using liquid chromatography/high-resolution mass spectrometry (LC-HRMS) and nuclear magnetic resonance (NMR). The absolute configuration of all $\alpha$-amino acids was determined by HPLC analysis after derivatization with Marfey's reagent and comparison with commercially available reference amino acids. Structure elucidation was pursued in the presented study by mass spectrometry and NMR spectral data. Petrocidin A (1) and 2,3-dihydroxybenzamide (3) exhibited significant cytotoxicity towards the human promyelocytic HL-60 and the human colon adenocarcinoma HT-29 cell lines. These results demonstrated the potential of sponge-associated actinomycetes for the discovery of novel and pharmacologically active natural products.
\end{abstract}

Keywords: sponges; actinomycetes; streptomyces; cyclic dipeptide; cytotoxic

\section{Introduction}

Marine sponges are sources for diverse and novel actinomycetes [1-4]. A multitude of secondary metabolites [5] have been recovered from marine sponge-associated actinomycetes that display diverse biological activities, such as antimicrobial [6-9], antiparasitic [10,11], immunomodulatory [12], antichlamydial [13], antioxidant [14], and anticancer [15,16] activities. The conventional natural products isolation scheme has however frequently been challenged owing to the repeated isolation of known compounds, the failure to isolate trace compounds and sometimes the loss of activity during fractionation and compound purification [17]. The lack of detailed chemical information prior to isolation is another draw-back of conventional natural product discovery. By comparison, the metabolomics approach comes with the significant advantage that different active compounds can be determined in crude extracts without comprehensive fractionation or prior isolation of the individual compound while still offering structural information [18-21]. Our previous study using 
metabolomics and dereplication tools revealed a chemically distinct strain Streptomyces sp. SBT348 by PCA analysis [22]. In the present study, we report on the isolation and structure elucidation of a new cyclic dipeptide, petrocidin A (1); three known compounds 2,3-dihydroxybenzoic acid (2), 2,3-dihydroxybenzamide (3), and maltol (4) from strain Streptomyces sp. SBT348; as well as the determination of their anti-proliferative properties against HL-60, HT29, and MCF-7 cancer cell lines.

\section{Results and Discussion}

\subsection{Isolation and Purification of Strain Streptomyces sp. SBT348}

Streptomyces sp. SBT348 (GenBank accession No. KP238417) was cultivated from the Mediterranean sponge Petrosia ficiformis that was collected from Milos, Greece [22]. Our study using metabolomics and dereplication tools prioritized the strain Streptomyces sp. SBT348 based on its chemical uniqueness by Principal Component Analysis (PCA) (Figure 1). The ethyl acetate extract of the solid culture of Streptomyces sp. SBT348 was fractionated by preparative HPLC to afford a new cyclic dipeptide (1), and three known compounds-2,3-dihydroxybenzoic acid (2) [23], 2,3-dihydroxybenzamide (3) [24], and maltol (4) [25]. The structures of compounds 2, 3, and 4 were determined based on the MS and NMR elucidation, as well as comparison to the literature and Integrated Spectral Database System of Organic Compounds developed by AIST (National Institute of Advanced Industrial Science and Technology). The structure elucidation of the new cyclic dipeptide compound $\mathbf{1}$ was discussed as follows.<smiles>CC(C)C[C@H](NC(=O)[C@H](CO)NC(=O)c1cccc(O)c1O)C(=O)O</smiles>

(1)<smiles>O=C(O)c1cccc(O)c1O</smiles>

(2)<smiles>NC(=O)c1cccc(O)c1O</smiles>

(3)<smiles>Cc1occc(=O)c1O</smiles>

(4)

Figure 1. Compounds isolated from outlying strain Streptomyces sp. SBT348; petrocidin A (1), 2,3-dihydroxybenzoic acid (2), 2,3-dihydroxybenzamide (3), and maltol (4).

\subsection{Structure Elucidation}

Compound 1 (1.8 mg, yield $0.49 \%$ ) was purified as a colorless solid. The following NMR spectral data were acquired using a $600 \mathrm{MHz}$ instrument: ${ }^{1} \mathrm{H},{ }^{13} \mathrm{C},{ }^{13} \mathrm{C}$-DEPT135 (Distortionless Enhancement by Polarization Transfer), ${ }^{1} \mathrm{H}_{-}{ }^{1} \mathrm{H}$ COSY (correlation spectroscopy), ${ }^{1} \mathrm{H}-{ }^{1} \mathrm{H}$ NOESY (Nuclear Overhauser effect spectroscopy), ${ }^{1} \mathrm{H}_{-}{ }^{13} \mathrm{C}$ HSQC (heteronuclear single quantum correlation), and ${ }^{1} \mathrm{H}_{-}{ }^{13} \mathrm{C} \mathrm{HMBC}$ (Heteronuclear Multiple Bond Correlation) (optimized to $J=8.3 \mathrm{~Hz}$ ) in MeOD- $d_{4}$, as well as ${ }^{1} \mathrm{H}_{-}{ }^{13} \mathrm{C}$ HMBC (optimized to $J=8.3 \mathrm{~Hz}$ ) in DMSO- $d_{6}$ and tabulated in Table 1 . The molecular formula was determined to be $\mathrm{C}_{18} \mathrm{H}_{25} \mathrm{~N}_{3} \mathrm{O}_{5}\left(\mathrm{~m} / z 386.1692[\mathrm{M}+\mathrm{Na}]^{+}\right.$calcd. for $\left.\mathrm{C}_{18} \mathrm{H}_{25} \mathrm{~N}_{3} \mathrm{O}_{5} \mathrm{Na}\right)$ from its HRESI-MS (High-Resolution Electrospray Ionization Mass Spectrometry) indicating eight degrees of unsaturation. The ${ }^{1} \mathrm{H}$ spectrum displayed three aromatic protons at $\delta_{\mathrm{H}} 6.98(1 \mathrm{H}, \mathrm{d}, J=7.8 \mathrm{~Hz}), 6.71(1 \mathrm{H}, \mathrm{t}, J=7.8$, $15.8 \mathrm{~Hz})$, and $7.34(1 \mathrm{H}, \mathrm{d}, J=7.8 \mathrm{~Hz}) \mathrm{ppm}$, three methine protons at $\delta_{\mathrm{H}} 1.89(1 \mathrm{H}, \mathrm{m}), 4.13(1 \mathrm{H}, \mathrm{t}, J=5.6$, $11.4 \mathrm{~Hz})$, and $4.26(1 \mathrm{H}, \mathrm{t}, J=8.5,16.1 \mathrm{~Hz})$, eight methylene protons at $\delta_{\mathrm{H}} 3.51(2 \mathrm{H}, \mathrm{t}, J=4.7,8.9 \mathrm{~Hz}), 2.30$ $(1 \mathrm{H}, \mathrm{m}), 2.02(1 \mathrm{H}, \mathrm{m}), 2.01(1 \mathrm{H}, \mathrm{m}), 1.94(1 \mathrm{H}, \mathrm{m}), 1.91(1 \mathrm{H}, \mathrm{m})$, and $1.52(1 \mathrm{H}, \mathrm{m}) \mathrm{ppm}$, and six methyl protons at $\delta_{\mathrm{H}} 0.96(3 \mathrm{H}, \mathrm{d}, J=3.7 \mathrm{~Hz})$ and $0.95(3 \mathrm{H}, \mathrm{d}, J=3.7 \mathrm{~Hz}) \mathrm{ppm} .{ }^{13} \mathrm{C},{ }^{3} \mathrm{C}-\mathrm{DEPT} 135$ and HSQC 
spectra displayed six aromatic carbons at $\delta_{C} 114.7,119.6,121.3,121.9,147.0$, and $151.7 \mathrm{ppm}$; three ester/amide-type carbonyls at $\delta_{C} 168.3,172.8$, and $174.2 \mathrm{ppm}$; three methine carbons at $\delta_{C} 60.3,54.6$, and $25.8 \mathrm{ppm}$; four methylene carbons at $\delta_{C} 23.7,29.1,39.4$, and $46.4 \mathrm{ppm}$; and two methyl carbons at $\delta_{\mathrm{C}} 22.2$ and $23.2 \mathrm{ppm}$. The three aromatic protons at $\delta_{\mathrm{H}} 6.98,6.71$, and $7.34 \mathrm{ppm}$ were assigned to $\mathrm{H}-4$, $\mathrm{H}-5$, and $\mathrm{H}-6$, respectively by COSY spectrum and indicated an adjacent three-substitution aromatic system as part of the structure. The deshielded carbon resonances at $\delta_{C} 151.7$ and $147.0 \mathrm{ppm}$ suggested two hydroxyl substitutions on the aromatic ring, and were assigned to $\mathrm{C}-2$ and $\mathrm{C}-3$ respectively, with the correlations observed amongst H-4, H-5, and H-6 in the HMBC spectrum (Figure 2). The other aromatic carbon resonances at $\delta_{C} 114.7,121.3,119.6,121.9$ ppm were attributed to C-1, C-4, C-5, C-6, respectively according to the cross-peaks observed in the HSQC and HMBC spectra. The strong correlation observed in the $\mathrm{HMBC}$ spectrum between $\mathrm{H}-6$ and one of the ester/amide-type carbonyls at $\delta_{C} 174.2 \mathrm{ppm}$ has assigned $\delta_{C} 174.2$ to $C-7$ (Figure 2). The HSQC and HMBC spectra also exhibited standard resonance signals for amino acids by the observation of two $\alpha$-methines signals at $\delta_{\mathrm{H}} 4.26$ $(1 \mathrm{H}, \mathrm{t}, J=8.5,16.1 \mathrm{~Hz}), 4.13(1 \mathrm{H}, \mathrm{t}, J=5.6,11.4 \mathrm{~Hz})$ with their connected deshielded carbons at $\delta_{\mathrm{C}} 60.3$ and $54.6 \mathrm{ppm}$, respectively, as well as HMBC cross-peaks between the $\alpha$-protons and ester/amide-type carbonyls at $\delta_{C} 172.8$ and 168.9 ppm (Figure 2). Analysis of the COSY, HSQC, and HMBC data, as well as degrees of unsaturation assigned one ornithine and one leucine moiety presented in a cyclic nature. The connection between the aromatic part and the cyclic peptide moiety was confirmed by the correlation displayed in HMBC (using DMSO- $d_{6}$ as solvent) between Orn $\beta-\mathrm{H}$ and C-7 (Figure 2). The proton and carbon resonances were also compared to the human metabolites database (HMDB) with ornithine and leucine individually, as well as 2,3-dihydroxybenzamide-scaffold with compound 2 and literature [24], and they showed consistent results. The absolute configuration of leucine and ornithine was determined by acid hydrolysis followed by Marfey's derivatization and comparison to their analogues of the authentic amino acids by HPLC analysis. The Marfey's analysis of compound 1 revealed the absolute configuration of leucine to be $\mathrm{L}$ and ornithine to be D-configuration. Compound 1 was identified as 2,3-dihydroxy-N-((3S,6R)-3-isobutyl-2,5-dioxo-1,4-diazonan-6-yl) benzamide, a new cyclic dipeptide, and given the name petrocidin $\mathrm{A}$.

Compounds 2, 3, and 4 were isolated as colorless solid from fraction 1, 2, and 5 respectively. The molecular formula was established as $\mathrm{C}_{7} \mathrm{H}_{6} \mathrm{O}_{4}$ (found at $\mathrm{EI} m / z$ 154.0, calcd. 154.0266) for compound 2, $\mathrm{C}_{7} \mathrm{H}_{7} \mathrm{NO}_{3}$ (found at $\mathrm{EI} m / z$ 153.0, calcd. 153.0426) for compound 3, and $\mathrm{C}_{6} \mathrm{H}_{6} \mathrm{O}_{3}$ (found at EI $m / z$ 126.0, calcd. 126.0317) for compound 4, respectively. An exact mass search in the Database of Natural Products (2015) and comparison of the spectral data with the literature determined compound $\mathbf{2}$ as 2,3-dihydroxybenzoic acid [26], compound $\mathbf{3}$ as 2,3-dihydroxybenzamide [24], and compound 4 as Maltol [27].

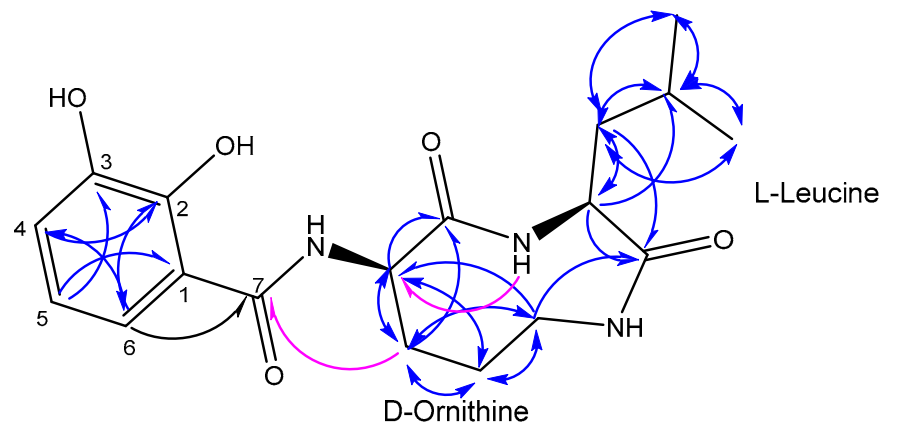

Figure 2. Structure of petrocidin A (1) with HMBC key correlations (blue, arrows from $\mathrm{H}$ to $\mathrm{C}$ in MeOD- $d_{4}$; Purple, key arrows from $\mathrm{H}$ to C in DMSO- $d_{6}$ ). 
Table 1. NMR-spectroscopic data of petrocidin A (1) in MeOD- $d_{4}$ and DMSO- $d_{6}\left(1 \mathrm{H}: 600 \mathrm{MHz} ;{ }^{13} \mathrm{C}\right.$ : $150 \mathrm{MHz})$.

\begin{tabular}{|c|c|c|c|c|c|}
\hline Position & $\delta_{C}$, Type & $\delta_{\mathrm{H}}(J, \mathrm{~Hz})$ & COSY & HMBC $^{a}$ & HMBC $^{\text {b }}$ \\
\hline 2 & $151.7, \mathrm{C}$ & - & - & - & - \\
\hline 4 & $121.3, \mathrm{CH}$ & $6.98(1 \mathrm{H}, \mathrm{d}, J=7.8 \mathrm{~Hz})$ & 6.71 & $151.7,147.0,121.9$ & - \\
\hline 5 & $119.6, \mathrm{CH}$ & $6.71(1 \mathrm{H}, \mathrm{t}, J=7.8 \mathrm{~Hz})$ & $6.98,7.34$ & $147.0,114.7,121.3$ & - \\
\hline 6 & $121.9, \mathrm{CH}$ & $7.34(1 \mathrm{H}, \mathrm{d}, J=7.8 \mathrm{~Hz})$ & 6.71 & $174.2,151.7,121.3$ & - \\
\hline $\mathrm{CO}$ & $172.8, \mathrm{C}$ & - & - & - & - \\
\hline$\alpha$ & $60.3, \mathrm{CH}$ & $4.26(1 \mathrm{H}, \mathrm{t}, J=8.5 \mathrm{~Hz})$ & $2.30,2.01$ & $172.8,29.1,23.7$ & - \\
\hline$\beta$ & 29.1, $\mathrm{CH}_{2}$ & $2.30(1 \mathrm{H}, \mathrm{m}), 2.01(1 \mathrm{H}, \mathrm{m})$ & $2.02,1.94$ & $46.4,23.7,60.3,172.8$ & $171.9(\mathrm{C}-7)$ \\
\hline$\gamma$ & 23.7, $\mathrm{CH}_{2}$ & $2.02(1 \mathrm{H}, \mathrm{m}), 1.94(1 \mathrm{H}, \mathrm{m})$ & $2.30,2.01,2.02,1.94$ & $29.1,60.3,46.4$ & - \\
\hline$\delta$ & $46.4, \mathrm{CH}_{2}$ & $3.51(2 \mathrm{H}, \mathrm{t}, J=4.7 \mathrm{~Hz})$ & $2.02,1.94$ & $168.9,29.1,23.7$ & - \\
\hline Leu & - & - & - & - & - \\
\hline $\mathrm{CO}$ & $168.9, \mathrm{C}$ & - & - & - & - \\
\hline$\alpha$ & $54.6, \mathrm{CH}$ & $4.13(1 \mathrm{H}, \mathrm{t}, J=5.6 \mathrm{~Hz})$ & $1.91,1.52$ & $168.9,39.4,25.8$ & - \\
\hline$\beta$ & $39.4, \mathrm{CH}_{2}$ & $1.52(1 \mathrm{H}, \mathrm{m}), 1.91(1 \mathrm{H}, \mathrm{m})$ & $1.89,4.13$ & $168.9,54.6,25.8,23.2,22.2$ & - \\
\hline$\gamma$ & $25.8, \mathrm{CH}$ & $1.89(1 \mathrm{H}, \mathrm{m})$ & $0.96,0.95,1.52,1.91$ & 39.4 & - \\
\hline \multirow{2}{*}{$\delta$} & \multirow{2}{*}{$22.2,23.2, \mathrm{CH}_{3}$} & $0.96(3 \mathrm{H}, \mathrm{d}, J=6.5 \mathrm{~Hz})$ & \multirow{2}{*}{1.89} & \multirow{2}{*}{$25.8,39.4$} & \multirow{2}{*}{-} \\
\hline & & $0.95(3 \mathrm{H}, \mathrm{d}, J=3.1,6.2 \mathrm{~Hz})$ & & & \\
\hline
\end{tabular}

${ }^{\mathbf{a}} \mathrm{HMBC}$ correlations, optimized for $8.3 \mathrm{~Hz}$ in MeOD- $d_{4}$, are from protons stated to the indicated carbon; ${ }^{\mathbf{b}} \mathrm{HMBC}$ correlations, optimized for $8.3 \mathrm{~Hz}$ in DMSO- $d_{6}$, are from protons stated to the indicated carbon.

\subsection{Biological Activities of Isolated Compounds}

Compounds 2,3-dihydroxybenzoic acid (2) and 2,3-dihydroxybenzamide (3) were both previously isolated from a marine alga-derived actinomycete strain USF-TC31 and exhibited potent antioxidant activity in DPPH (2,2-Diphenyl-1-picrylhydrazyl) radical scavenging assay [24]. 2,3-dihydroxybenzoic acid (2) was also identified as the precursor of a group of catecholate siderophores which were described from Vibrio sp. and Salmonella sp. embedding with the substructure of 2,3-dihydroxybenzamide [27-31]. The new compound petrocidin A (1) enclosing the moiety of 2,3-dihydroxybenzamide as part of the structure indicated that 2,3-dihydroxybenzoic acid (2) might be the direct precursor of petrocidin A (1). Maltol (4) was previously reported from different plants [24,32,33], but was also isolated as a bacterial metabolite from Streptomyces sp. GW3/1538 [34].

Microsomal prostaglandin $\mathrm{E}_{2}$ synthase-1 (mPGES-1) has been reported to be over-expressed in a group of tumor cells-such as HL-60, HT-29, and MCF-7 cell lines-but not in normal tissues [35,36]. The moiety of 2,3-dihydroxybenzamide was proposed as an active scaffold in the search for new mPGES-1 inhibitors used in anti-inflammatory and anticancer process [37]. The anti-proliferative properties of the four compounds were evaluated against the three cancer cell lines including the HL-60, HT-29, and MCF-7 cell lines. Petrocidin A (1) displayed significant cytotoxic effects towards HL-60 and HT-29 cells with the $\mathrm{IC}_{50}$ values of 3.9 and $5.3 \mu \mathrm{g} / \mathrm{mL}$, respectively. While, 2,3-Dihydroxybenzamide (3) exhibited potent cytotoxicity towards the same two cell lines with the $\mathrm{IC}_{50}$ values of 5.5 , and $3.8 \mu \mathrm{g} / \mathrm{mL}$, respectively. 2,3-Dihydroxybenzoic acid (2) and maltol (4) did not exhibit any significant cytotoxicity at the examined concentrations. These results suggested that the new cyclic dipeptide petrocidin A (1) and 2,3-dihydroxybenzamide (3) which is a part of the peptidic structure exhibiting anti-proliferative effects towards HL-60 and HT29 cancer cell lines which might be as mPGES-1 inhibitors. 


\section{Materials and Methods}

\subsection{Cell Lines, Chemicals, and Biochemical}

HL-60 cells (human promyelocytic cell) were grown in 5\% $(v / v) \mathrm{CO}_{2}$ in RPMI 1640 medium at $37{ }^{\circ} \mathrm{C}$, supplemented with $10 \%(v / v) 1 \%(w / v)$ L-glutamine, and $0.4 \%(w / v)$ antibiotics $(50 \mathrm{U} / \mathrm{mL}$ penicillin and $50 \mathrm{mg} / \mathrm{mL}$ streptomycin). The HT-29 cells (human colon adenocarcinoma cell) were cultured at $37^{\circ} \mathrm{C}, 5 \%(v / v) \mathrm{CO}_{2}$ in Dulbecco's modified Eagle medium (DMEM) with high glucose $(4.5 \mathrm{~g} / \mathrm{L})$ supplemented with $10 \%(v / v)$ fetal bovine serum (FBS), $1 \%(w / v)$ L-glutamine, and $0.4 \%(w / v)$ antibiotics (50 U/mL penicillin, $50 \mathrm{mg} / \mathrm{mL}$ streptomycin). MCF-7 cells (Human breast adenocarcinoma cell) were cultured at $37{ }^{\circ} \mathrm{C}, 5 \%(v / v) \mathrm{CO}_{2}$ in RPMI1640 medium, supplemented with $5 \%(v / v)$ fetal bovine serum (FBS), 1\% (w/v) L-glutamine, 1\% sodium pyruvate and $0.4 \%(w / v)$ antibiotics $(50 \mathrm{U} / \mathrm{mL}$ penicillin, $50 \mathrm{mg} / \mathrm{mL}$ streptomycin). Cells were obtained from the American Type Culture Collection (ATCC, Rockville, MD, USA; HPACC, Salisbury, UK) and routinely sub-cultured twice per week. All chemicals and reagents were purchased from Sigma Aldrich (Darmstadt, Germany).

\subsection{Bacteria}

Streptomyces sp. SBT348 (GeneBank accession No. KP238417) was recovered from the Mediterranean sponge Petrosia ficiformis which was collected by SCUBA diving from offshore Pollonia, Milos, Greece $\left(36.76612^{\circ} \mathrm{N} ; 24.51530^{\circ} \mathrm{E}\right)$ at 5-7 $\mathrm{m}$ depth in May 2013.

\subsection{Large-Scale Fermentation, Extraction, and Isolation}

Three hundred ISP2 agar plates (square $120 \times 120 \mathrm{~mm}$ ), each inoculated with $100 \mu \mathrm{L}$ of five days liquid culture of Streptomyces sp. SBT348 respectively were incubated at $30^{\circ} \mathrm{C}$ for seven days. The agar media with bacterial biomass were scalped into small pieces and transferred to 1 L Erlenmeyer flasks. Five hundred $\mathrm{mL}$ of ethyl acetate/flask were added to submerge the agar pieces and macerated the medium culture under shaking at $175 \mathrm{rpm}$ for overnight. The macerations were subsequently filtered by gravity using filter paper (A. Hartenstein, Würzburg, Germany). The filtrates were combined and evaporated by under vacuum (Büchi, Essen, Germany). Three-hundred and seventy mg of the dried crude EtOAc extract obtained from the solid culture of strain Streptomyces sp. SBT348 was fractionated by semi-preparative HPLC (Agilent, Waldbronn, Germany) using $\mathrm{H}_{2} \mathrm{O} / \mathrm{ACN}$ (95\%:5\%) initially for 5 min, then by a linear gradient to $100 \%$ ACN within $40 \mathrm{~min}$, which was followed by an isocratic condition of 100\% ACN for a further $5 \mathrm{~min}$ on the Prep C18 column $(5 \mu \mathrm{m}, 10 \times 250 \mathrm{~mm}$, (Waters XBridge, Eschborn, Germany), with a flow rate of $3.0 \mathrm{~mL} / \mathrm{min}$ to yield five fractions. Compounds $1-4$ were purified from peaks rich fraction Nr. 3 by semi-preparative HPLC using Onyx Monolithic semi-prep RP-C18 column (5 $\mu \mathrm{m}, 10 \times 100 \mathrm{~mm}$, Phenomenex, Aschaffenburg, Germany).

\subsection{LC-MS Analysis}

Accurate electrospray ionization mass spectra (ESI) were obtained by a Synapt G2 HDMS qTOF-Mass Spectrometer (Waters, Eschborn, Germany). The ESI was operated in the positive and negative ionization modes. The capillary voltage was set to $0.8 \mathrm{kV}$ and nitrogen (at $350{ }^{\circ} \mathrm{C}$, the flow rate of $800 \mathrm{~L} / \mathrm{h}$ ) was used as desolvation gas. The molecular ion was determined by quadrupole in a wide-band RF mode, and data was acquired over the mass range of 50-1200 Da. Product ion scan was optimized for different analyses using different collision voltage from 10 to $25 \mathrm{eV}$. MassLynx (version 4.1, Waters, Bremen, Germany) was utilized to acquire and process mass spectrum.

\subsection{Marfey's Analysis}

The absolute configuration of $\alpha-\mathrm{H}$ that presented in compound 4 was performed by Marfey's derivatization and compared to the purchased amino acid with D and L configurations (Sigma, Darmstadt, Germany) by HPLC. Compound $4(0.8 \mathrm{mg})$ was initially hydrolyzed with $6 \mathrm{M} \mathrm{HCl}$ 
$(2 \mathrm{~mL})$ in the water bath at $100{ }^{\circ} \mathrm{C}$ for $24 \mathrm{~h}$. The hydrolysate was cooled to room temperature, dried using vacuum evaporator, and finally dissolved in $100 \mu \mathrm{L}$ of water. The Marfey's derivatization was carried out by adding $100 \mu \mathrm{L}$ of $1 \%$ Marfey's reagent (1-Fluoro-2,4-dinitrophenyl-5-L-alanine amid) dissolved in acetone and $20 \mu \mathrm{L}$ of $1 \mathrm{M} \mathrm{NaHCO}_{3}\left(\mathrm{H}_{2} \mathrm{O}\right)$ to $50 \mu \mathrm{L}$ of the hydrolysate of compound 4, as well as $50 \mathrm{mM}$ standard amino acid (D-Leu, L-Leu, D-Orn, and L-Orn) respectively, and incubated at $40{ }^{\circ} \mathrm{C}$ for $1 \mathrm{~h}$ with frequent shaking. The reaction was stopped by adding $10 \mu \mathrm{L}$ of $2 \mathrm{M} \mathrm{HCl}$ after cooling. The Marfey's derivatization products were finally dried and prepared in $\mathrm{MeOH}$ for further HPLC analysis. The HPLC chromatography was carried out on Gemini-NX RP-C18 column (Phenomenex, Aschaffenburg, Germany by eluting with $\mathrm{H}_{2} \mathrm{O} / \mathrm{CH}_{3} \mathrm{CN}$ (95\%:5\%) for the first 5 min, linearly gradient to $100 \% \mathrm{CH}_{3} \mathrm{CN}$ within $25 \mathrm{~min}$, and held at $100 \% \mathrm{CH}_{3} \mathrm{CN}$ for a further 5 min with a flow rate at $1 \mathrm{~mL} / \mathrm{min}$ and $\mathrm{UV}$ detection at $340 \mathrm{~nm}$. The configuration was eventually determined with the observation of the same retention times compared to the purchased standard enantiomeric amino acids (Bhushan and Bruckner, 2004; Kochhar and Christen, 1989; Marfey, 1984).

\subsection{MTT ((3-(4,5-Dimethylthiazol-2-yl)-2,5-diphenyltetrazolium bromide)) Assay}

Cell proliferation was evaluated in cell lines by the MTT assay in triplicates. Briefly, cells were plated in a 96-well microtiter plate at a density of $1 \times 10^{4}$ cells per well in a final volume of $100 \mu \mathrm{L}$ of culture medium. These cells were treated for $24 \mathrm{~h}$ with tested compound at $37^{\circ} \mathrm{C}$ with $5 \% \mathrm{CO}_{2}$. After treatment, the cells were immediately incubated with $10 \mu \mathrm{L} \mathrm{MTT}(5.0 \mathrm{mg} / \mathrm{mL})$ for $4 \mathrm{~h}$ at $37^{\circ} \mathrm{C}$. The cells were lysed in $100 \mu \mathrm{L}$ of lysis buffer (isopropanol, conc. $\mathrm{HCl}$ and Triton X-100) for $10 \mathrm{~min}$ at room temperature and $300 \mathrm{rpm} / \mathrm{min}$ shaking. The enzymatic reduction of MTT to formazan crystals that dissolved in DMSO was quantified by photometry at $570 \mathrm{~nm}$. Dose-response curves were generated and the $\mathrm{IC}_{50}$ values were defined as the concentration of compound required to inhibit cell proliferation by $50 \%$. 5-Flurouracil was used as a positive control.

\subsection{Compounds Characterization}

\subsubsection{Petrocidin A (1)}

Colorless solid (1.8 mg, $\left.R_{\mathrm{t}}=14.72 \mathrm{~min}\right) ; \mathrm{UV}(\mathrm{EtOH}) \lambda_{\max } 220,320 \mathrm{~nm}$; IR (KBr) $v_{\max } 4376,4203,3353$, 1859, 1616, 1500, $1204 \mathrm{~cm}^{-1} ;{ }^{1} \mathrm{H}$ NMR (MeOD- $\left.d_{4}, 600 \mathrm{MHz}\right): \delta=6.98(1 \mathrm{H}, \mathrm{d}, J=7.8 \mathrm{~Hz}, \mathrm{H}-4), 6.71(1 \mathrm{H}$, $\mathrm{t}, J=7.8 \mathrm{~Hz}, \mathrm{H}-5), 7.23(1 \mathrm{H}, \mathrm{d}, J=7.8 \mathrm{~Hz}, \mathrm{H}-6), 4.26(1 \mathrm{H}, \mathrm{t}, J=8.5 \mathrm{~Hz}$, Orn $\alpha$-proton), $2.30(1 \mathrm{H}, \mathrm{m}$, Orn $\beta$-proton), 2.01 (1H, m, Orn $\beta$-proton), $2.02(1 \mathrm{H}, \mathrm{m}$, Orn $\gamma$-proton), $1.94(1 \mathrm{H}, \mathrm{m}$, Orn $\gamma$-proton), $3.51(2 \mathrm{H}, \mathrm{t}$, $J=4.7 \mathrm{~Hz}$, Orn $\delta$-proton), $4.13(1 \mathrm{H}, \mathrm{t}, J=5.6 \mathrm{~Hz}$, Leu $\alpha$-proton), $1.52(1 \mathrm{H}, \mathrm{m}$, Leu $\beta$-proton), $1.91(1 \mathrm{H}, \mathrm{m}$, Leu $\beta$-proton), 1.89 ( $1 \mathrm{H}, \mathrm{m}$, Leu $\gamma$-proton), $0.96(3 \mathrm{H}, \mathrm{d}, J=3.7 \mathrm{~Hz}$, Leu $\delta$-proton), 0.95 (3H, d, $J=3.7 \mathrm{~Hz}$, Leu $\delta$-proton) ppm. ${ }^{1} \mathrm{H}$ NMR (DMSO- $d_{6}, 600 \mathrm{MHz}$ ): $8.02\left(1 \mathrm{H}, \mathrm{s}\right.$, Leu NH). ${ }^{13} \mathrm{C}$ NMR (MeOD- $d_{4}, 150 \mathrm{MHz}$ ): $\delta=114.7(\mathrm{C}, \mathrm{C}-1), 151.7$ (C, C-2), 147.0 (C, C-3), $121.3(\mathrm{CH}, \mathrm{C}-4), 119.6$ (CH, C-5), 121.9 (CH, C-6), $174.2(\mathrm{C}$, C-7), 172.8 (C, Orn CO), 60.3 (1C, Orn $\alpha$-carbon), 29.1 (1C, Orn $\beta$-carbon), 23.7 (1C, Orn $\gamma$-carbon), 46.4 (1C, Orn $\delta$-carbon), 168.9 (1C, Leu CO), 54.6 (1C, Leu $\alpha$-carbon), 39.4 (1C, $\beta$-carbon), 25.8 (1C, $\gamma$-carbon), 22.2 (1C, $\delta$-carbon), 23.2 (1C, $\delta$-carbon). ESI-HRMS $m / z 383.1692\left[\mathrm{M}+\mathrm{Na}^{+}, \mathrm{C}_{18} \mathrm{H}_{25} \mathrm{~N}_{3} \mathrm{O}_{5} \mathrm{Na}\right.$ (calcd. 383.1691); Anal. Calcd. for $\mathrm{C}_{18} \mathrm{H}_{25} \mathrm{~N}_{3} \mathrm{O}_{5} \mathrm{Na}$ : C, 59.49; $\mathrm{H}, 6.93 ; \mathrm{N}, 11.56 ; \mathrm{O}, 22.01$.

\subsubsection{2,3-Dihydroxybenzoic Acid (2)}

White solid (2.7 mg, $\left.R_{\mathrm{t}}=12.30 \mathrm{~min}\right)$; UV (EtOH) $\lambda_{\max } 254,320 \mathrm{~nm}$; IR (KBr) $v_{\max } 3664,1980,1506$, $1035 \mathrm{~cm}^{-1} ;{ }^{1} \mathrm{H}$ NMR $\left(\mathrm{MeOD}-d_{4}, 600 \mathrm{MHz},\right): \delta=6.95(1 \mathrm{H}, \mathrm{dd}, J=7.9,1.5 \mathrm{~Hz}, \mathrm{H}-4), 6.71(1 \mathrm{H}, \mathrm{t}, J=8.3 \mathrm{~Hz}$, $\mathrm{H}-5), 7.24$ (3H, dd, $J=7.9,1.5 \mathrm{~Hz}, \mathrm{H}-6) ;{ }^{13} \mathrm{C} \mathrm{NMR}\left(\mathrm{MeOD}-d_{4}, 150 \mathrm{MHz},\right): \delta=115.9(\mathrm{C}, \mathrm{C}-1), 151.1(\mathrm{C}$, C-2), 147.3 (C, C-3), 120.0 (CH, C-4), 119.5 (CH, C-5), 119.4 (CH, C-6), 174.5 (C, C-7); EI 153.0 Dalton, $\mathrm{C}_{7} \mathrm{H}_{7} \mathrm{NO}_{3}$ (calcd. 153.0426); Anal. Calcd. for $\mathrm{C}_{7} \mathrm{H}_{7} \mathrm{NO}_{3}: \mathrm{C}, 54.90 ; \mathrm{H}, 4.61 ; \mathrm{N}, 9.15 ; \mathrm{O}, 34.31$. 


\subsubsection{2,3-Dihydroxybenzamide (3)}

White soild ( $\left.2.3 \mathrm{mg}, R_{\mathrm{t}}=9.94 \mathrm{~min}\right) ; \mathrm{UV}(\mathrm{EtOH}) \lambda_{\max } 247,310 \mathrm{~nm}$; IR (KBr) $v_{\max } 3571,2014,1868$, 1458, $1227 \mathrm{~cm}^{-1} ;{ }^{1} \mathrm{H}$ NMR (DMSO- $\left.d_{6}, 600 \mathrm{MHz}\right): \delta=6.98(1 \mathrm{H}, \mathrm{dd}, J=7.8,1.6 \mathrm{~Hz}, \mathrm{H}-4), 6.71(1 \mathrm{H}, \mathrm{t}$, $J=7.8 \mathrm{~Hz}, \mathrm{H}-5), 7.24(1 \mathrm{H}, \mathrm{dd}, J=7.8,1.6 \mathrm{~Hz}, \mathrm{H}-6) ;{ }^{13} \mathrm{C}$ NMR $\left(\mathrm{DMSO}-d_{6}, 150 \mathrm{MHz},\right): \delta=113.5(\mathrm{C}, \mathrm{C}-1)$, 150.5 (C, C-2), 145.9 (C, C-3), 120.5 (CH, C-4), 118.4 (CH, C-5), 120.0 (CH, C-6), 172.5 (C, C-7); EI 154.0 Dalton, $\mathrm{C}_{7} \mathrm{H}_{6} \mathrm{O}_{4}$ (calcd. 154.0266); Anal. Calcd. for $\mathrm{C}_{7} \mathrm{H}_{6} \mathrm{O}_{4}$ : $\mathrm{C}$, 54.55; $\mathrm{H}, 3.92 ; \mathrm{O}, 41.52$.

\subsubsection{Maltol (4)}

Colorless solid (1.6 mg, $\left.R_{\mathrm{t}}=11.72 \mathrm{~min}\right)$ ); UV (EtOH) $\lambda_{\max } 220,284 \mathrm{~nm}$; IR (KBr) $v_{\max } 3928,1936$, 1313, $293 \mathrm{~cm}^{-1}$; ${ }^{1} \mathrm{H}$ NMR (MeOD- $\left.d_{4}, 600 \mathrm{MHz},\right): \delta=6.38(1 \mathrm{H}, \mathrm{d}, J=5.5 \mathrm{~Hz}, \mathrm{H}-5), 7.94(1 \mathrm{H}, \mathrm{d}, J=5.5 \mathrm{~Hz}$, H-6), 2.35 (3H, s, H-7); ${ }^{13} \mathrm{C}$ NMR (MeOD-d $d_{4}, 150 \mathrm{MHz}$ ): $\delta=152.2(\mathrm{C}, \mathrm{C}-2), 144.6$ (C, C-3), 175.3 (C, C-4), 114.4 (CH, C-5), 156.3 (CH, C-6), 14.2 (CH3, C-7); EI 126.0 Dalton, $\mathrm{C}_{6} \mathrm{H}_{6} \mathrm{O}_{3}$ (calcd. 126.0317); Anal. Calcd. for $\mathrm{C}_{6} \mathrm{H}_{6} \mathrm{O}_{3}$ : C, 57.14; $\mathrm{H}, 4.80 ; \mathrm{O}, 38.06$.

\section{Conclusions}

In summary, four compounds including a new cyclic dipeptide, petrocidin A (1), and three known compounds-2,3-dihydroxybenzoic acid (2), 2,3-dihydroxybenzamide (3), and maltol (4)-were isolated from the solid culture of Streptomyces sp. SBT348 which was derived from marine sponge Petrosia ficiformis. The new cyclic dipeptide petrocidin A (1) and the known 2,3-dihydroxybenzamide (3) displayed cytotoxicity against HL-60 and HT-29 cancer cell lines. These results demonstrated that sponge-associated actinomycetes are a promising source for the discovery of novel and pharmacologically active natural products.

Acknowledgments: This work was supported by the SeaBioTech project that is funded by the European Commission within its FP7 Programme, under the thematic area KBBE.2012.3.2-01 (grant number 311932). We wish to thank Xiao Wang (UCSan Diego, USA) for helpful discussions, Matthias Grüne for NMR data acquisition and Michael Büchner for mass spectrometry data acquisition (both University of Würzburg, Germany) and Simon Zobus (Toxicology department, Würzburg, Germany) for his technical assistance. We hereby confirm that the isolate Streptomyces SBT348 was collected during our EUH2020 Project "SeaBioTech". We further confirm that these collection efforts comply with the "The Nagoya Protocol on Access to Genetic Resources and the Fair and Equitable Sharing of Benefits Arising from their Utilization to the Convention on Biological Diversity".

Author Contributions: Cheng Cheng isolated the compounds and performed data acquisition and structure elucidation, as well as writing the manuscript; Eman M. Othman and Helga Stopper conducted the cytotoxicity assay and contributed to manuscript writing; Usama Ramadan Abdelmohsen designed and guided the whole experiment and structure elucidation; RuAngelie Edrada-Ebel and Ute Hentschel drafted and revised the manuscript.

Conflicts of Interest: The authors declare no conflict of interest.

\section{References}

1. Nouioui, I.; Ruckert, C.; Willemse, J.; van Wezel, G.P.; Klenk, H.P.; Busche, T.; Kalinowski, J.; Bredholt, H.; Zotchev, S.B. Actinoalloteichus fjordicus sp. nov. isolated from marine sponges: Phenotypic, chemotaxonomic and genomic characterisation. Anton Leeuwenhoek 2017, 110, 1705-1717. [CrossRef] [PubMed]

2. De Menezes, C.B.A.; Afonso, R.S.; de Souza, W.R.; Parma, M.; de Melo, I.S.; Zucchi, T.D.; Fantinatti-Garboggini, F. Williamsia spongiae sp nov., an actinomycete isolated from the marine sponge Amphimedon viridis. Int. J. Syst. Evol. Microbiol. 2017, 67, 1260-1265.

3. Hentschel, U.; Piel, J.; Degnan, S.M.; Taylor, M.W. Genomic insights into the marine sponge microbiome. Nat. Rev. Microbiol. 2012, 10, 641-654. [CrossRef] [PubMed]

4. Abdelmohsen, U.R.; Grkovic, T.; Balasubramanian, S.; Kamel, M.S.; Quinn, R.J.; Hentschel, U. Elicitation of secondary metabolism in actinomycetes. Biotechnol. Adv. 2015, 33, 798-811. [CrossRef] [PubMed]

5. Abdelmohsen, U.R.; Bayer, K.; Hentschel, U. Diversity, abundance and natural products of marine sponge-associated actinomycetes. Nat. Prod. Rep. 2014, 31, 381-399. [CrossRef] [PubMed] 
6. Jimenez-Romero, C.; Rode, J.E.; Perez, Y.M.; Franzblau, S.G.; Rodriguez, A.D. Exploring the Sponge Consortium Plakortis symbiotica-Xestospongia deweerdtae as a Potential Source of Antimicrobial Compounds and Probing the Pharmacophore for Antituberculosis Activity of Smenothiazole A by Diverted Total Synthesis. J. Nat. Prod. 2017, 80, 2295-2303. [CrossRef] [PubMed]

7. Van der Meij, A.; Worsley, S.F.; Hutchings, M.I.; van Wezel, G.P. Chemical ecology of antibiotic production by actinomycetes. FEMS Microbiol. Rev. 2017, 41, 392-416. [CrossRef] [PubMed]

8. Eltamany, E.E.; Abdelmohsen, U.R.; Ibrahim, A.K.; Hassanean, H.A.; Hentschel, U.; Ahmed, S.A. New antibacterial xanthone from the marine sponge-derived Micrococcus sp. EG45. Bioorg. Med. Chem. Lett. 2014, 24, 4939-4942. [CrossRef] [PubMed]

9. Hentschel, U.; Schmid, M.; Wagner, M.; Fieseler, L.; Gernert, C.; Hacker, J. Isolation and phylogenetic analysis of bacteria with antimicrobial activities from the Mediterranean sponges Aplysina aerophoba and Aplysina cavernicola. FEMS Microbiol. Ecol. 2001, 35, 305-312. [CrossRef] [PubMed]

10. Abdelmohsen, U.R.; Cheng, C.; Viegelmann, C.; Zhang, T.; Grkovic, T.; Ahmed, S.; Quinn, R.J.; Hentschel, U.; Edrada-Ebel, R. Dereplication strategies for targeted isolation of new antitrypanosomal actinosporins A and B from a marine sponge associated-Actinokineospora sp. EG49. Mar. Drugs 2014, 12, 1220-1244. [CrossRef] [PubMed]

11. Viegelmann, C.; Parker, J.; Ooi, T.; Clements, C.; Abbott, G.; Young, L.; Kennedy, J.; Dobson, A.D.; Edrada-Ebel, R. Isolation and identification of antitrypanosomal and antimycobacterial active steroids from the sponge Haliclona simulans. Mar. Drugs 2014, 12, 2937-2952. [CrossRef] [PubMed]

12. Tabares, P.; Pimentel-Elardo, S.M.; Schirmeister, T.; Hunig, T.; Hentschel, U. Anti-protease and immunomodulatory activities of bacteria associated with Caribbean sponges. Mar. Biotechnol. (N. Y.) 2011, 13, 883-892. [CrossRef] [PubMed]

13. Reimer, A.; Blohm, A.; Quack, T.; Grevelding, C.G.; Kozjak-Pavlovic, V.; Rudel, T.; Hentschel, U.; Abdelmohsen, U.R. Inhibitory activities of the marine streptomycete-derived compound SF2446A2 against Chlamydia trachomatis and Schistosoma mansoni. J. Antibiot. 2015, 68, 674-679. [CrossRef] [PubMed]

14. Grkovic, T.; Abdelmohsen, U.R.; Othman, E.M.; Stopper, H.; Edrada-Ebel, R.; Hentschel, U.; Quinn, R.J. Two new antioxidant actinosporin analogues from the calcium alginate beads culture of sponge-associated Actinokineospora sp. strain EG49. Bioorg. Med. Chem. Lett. 2014, 24, 5089-5092. [CrossRef] [PubMed]

15. Yi-Lei, N.; Yun-Dan, W.; Chuan-Xi, W.; Ru, L.; Yang, X.; Dong-Sheng, F.; Hong, J.; Yun-Yang, L. Compounds from marine-derived Verrucosispora sp. FIM06054 and their potential antitumour activities. Nat. Prod. Res. 2014, 28, 2134-2139. [CrossRef] [PubMed]

16. Simmons, L.; Kaufmann, K.; Garcia, R.; Schwar, G.; Huch, V.; Muller, R. Bendigoles D-F, bioactive sterols from the marine sponge-derived Actinomadura sp. SBMs009. Bioorg. Med. Chem. 2011, 19, 6570-6575. [CrossRef] [PubMed]

17. Inui, T.; Wang, Y.; Pro, S.M.; Franzblau, S.G.; Pauli, G.F. Unbiased evaluation of bioactive secondary metabolites in complex matrices. Fitoterapia 2012, 83, 1218-1225. [CrossRef] [PubMed]

18. Hou, Y.; Braun, D.R.; Michel, C.R.; Klassen, J.L.; Adnani, N.; Wyche, T.P.; Bugni, T.S. Microbial strain prioritization using metabolomics tools for the discovery of natural products. Anal. Chem. 2012, 84, 4277-4283. [CrossRef] [PubMed]

19. Harvey, A.L.; Edrada-Ebel, R.; Quinn, R.J. The re-emergence of natural products for drug discovery in the genomics era. Nat. Rev. Drug Discov. 2015, 14, 111-129. [CrossRef] [PubMed]

20. Krug, D.; Muller, R. Secondary metabolomics: The impact of mass spectrometry-based approaches on the discovery and characterization of microbial natural products. Nat. Prod. Rep. 2014, 31, 768-783. [CrossRef] [PubMed]

21. Hall, R.; Beale, M.; Fiehn, O.; Hardy, N.; Sumner, L.; Bino, R. Plant Metabolomics: The missing link in functional genomics strategies. Plant Cell 2002, 14, 1437-1440. [CrossRef] [PubMed]

22. Cheng, C.; MacIntyre, L.; Abdelmohsen, U.R.; Horn, H.; Polymenakou, P.N.; Edrada-Ebel, R.; Hentschel, U. Biodiversity, anti-trypanosomal activity screening, and metabolomic profiling of actinomycetes isolated from Mediterranean sponges. PLoS ONE 2015, 10, e0138528. [CrossRef] [PubMed]

23. Corbin, J.L.; Bulen, W.A. The isolation and identification of 2,3-dihydroxybenzoic acid and 2-N,6-N-di-92,3-dihydroxybenzoyl)-L-lysine formed by iron-deficient Azotobacter vinelandii. Biochemistry 1969, 8, 757-762. [CrossRef] [PubMed] 
24. Sugiyama, Y.; Hirota, A. New potent DPPH radical scavengers from a marine-derived actinomycete strain USF-TC31. Biosci. Biotechnol. Biochem. 2009, 73, 2731-2734. [CrossRef] [PubMed]

25. Samejo, M.Q.; Ndukwe, G.I.; Burdi, D.K.; Bhanger, M.I.; Khan, K.M. Isolation and crystal structure of maltol from Abies pindrow. J. Med. Plants Res. 2009, 3, 55-60.

26. Feistner, G.J.; Beaman, B.L. Characterization of 2,3-dihydroxybenzoic acid from Nocardia asteroides GUH-2. J. Bacteriol. 1987, 169, 3982-3987. [CrossRef] [PubMed]

27. Aoyagi, N.; Kimura, R.; Murata, T. Isolation of maltol and pharmacological action of maltol and ethyl maltol. Chem. Pharm. Bull. 1974, 22, 1008-1013. [CrossRef] [PubMed]

28. Pollack, J.R.; Ames, B.N.; Neilands, J.B. Iron transport in Salmonella typhimurium: Mutants blocked in the biosynthesis of enterobactin. J. Bacteriol. 1970, 104, 635-639. [PubMed]

29. Chen, Q.; Actis, L.A.; Tolmasky, M.E.; Crosa, J.H. Chromosome-mediated 2,3-dihydroxybenzoic acid is a precursor in the biosynthesis of the plasmid-mediated siderophore anguibactin in Vibrio anguillarum. J. Bacteriol. 1994, 176, 4226-4234. [CrossRef] [PubMed]

30. Soengas, R.G.; Anta, C.; Espada, A.; Paz, V.; Ares, I.R.; Balado, M.; Rodríguez, J.; Lemos, M.L.; Jiménez, C. Structural characterization of vanchrobactin, a new catechol siderophore produced by the fish pathogen Vibrio anguillarum serotype $\mathrm{O}_{2}$. Tetrahedron Lett. 2006, 47, 7113-7116. [CrossRef]

31. Balado, M.; Osorio, C.R.; Lemos, M.L. A gene cluster involved in the biosynthesis of vanchrobactin, a chromosome-encoded siderophore produced by Vibrio anguillarum. Microbiology 2006, 152, 3517-3528. [CrossRef] [PubMed]

32. Ushanova, V.M.; Ziganshin, A.V.; Repyakh, S.M. Isolation of maltol from Siberian fir bark by the carbon dioxide method. Chem. Nat. Comp. 1998, 34, 104-105. [CrossRef]

33. Dean, F.M. Naturally occuring oxygen ring compounds. Chem. Abstr. 1963, 59, 640-649.

34. Maskey, R.P.; Shaaban, M.; Grun-Wollny, I.; Laatsch, H. Quinazolin-4-one derivatives from Streptomyces isolates. J. Nat. Prod. 2004, 67, 1131-1134. [CrossRef] [PubMed]

35. Li, Y.; Yin, S.; Nie, D.; Xie, S.; Ma, L.; Wang, X.; Wu, Y.; Xiao, J. MK886 inhibits the proliferation of HL-60 leukemia cells by suppressing the expression of mPGES-1 and reducing prostaglandin E2 synthesis. Int. J. Hematol. 2011, 94, 472-478. [CrossRef] [PubMed]

36. Elander, N.; Zhou, J.; Ungerback, J.; Dimberg, J.; Soderkvist, P. Association between adenomatosis polyposis coli functional status and microsomal prostaglandin E synthase-1 expression in colorectal cancer. Mol. Carcinog. 2009, 48, 401-407. [CrossRef] [PubMed]

37. Lauro, G.; Tortorella, P.; Bertamino, A.; Ostacolo, C.; Koeberle, A.; Fischer, K.; Bruno, I.; Terracciano, S.; Gomez-Monterrey, I.M.; Tauro, M.; et al. Structure-based design of microsomal prostaglandin E2 Synthase-1 (mPGES-1) inhibitors using a virtual fragment growing optimization scheme. ChemMedChem 2016, 11, 612-619. [CrossRef] [PubMed]

(c) 2017 by the authors. Licensee MDPI, Basel, Switzerland. This article is an open access article distributed under the terms and conditions of the Creative Commons Attribution (CC BY) license (http://creativecommons.org/licenses/by/4.0/). 